\title{
Corporate Social Responsibility strategies in the utilities sector: A comparative study
}

Arena, M., Azzone, G., Mapelli, F. $\left(^{*}\right)$

Marika Arena

Full professor

Department of Management, Economics and Industrial Engineering, Politecnico di Milano via Lambruschini 4/b, 20156 Milan - Italy

+390223994070

marika.arena@polimi.it

Giovanni Azzone

Full professor

Department of Management, Economics and Industrial Engineering, Politecnico di Milano via Lambruschini 4/b, 20156 Milan - Italy

+3902 23993981

giovanni.azzone@polimi.it

Francesca Mapelli $\left({ }^{*}\right)$ corresponding author

Post-doc researcher

Department of Management, Economics and Industrial Engineering, Politecnico di Milano via Lambruschini 4/b, 20156 Milan - Italy

+3902 23994071

francesca.mapelli@polimi.it 


\section{Corporate Social Responsibility strategies in the utilities sector: A comparative study}

\section{Abstract}

This paper aims to study the institutional dynamics that characterize the development of a CSR strategy in a specific industry, the utilities industry, and analyses how these dynamics can result in heterogeneity and diversity in companies' CSR strategies. The conceptual framework is provided by previous works in the field of CSR that identify the dimensions along which CSR is evolving and the institutional forces that influence companies' choices with respect to CSR strategies. The empirical analysis is based on a multiple case study of three utilities operating in Italy with data collected through various sources, including analysis of documents and semi-structured interviews. The case analysis shows how the interplay of various institutional logics provides a relevant explanation for both similarities and differences in the strategies enacted by the companies. Some pressures are dominant at the industry level, leading to homogeneity in the strategies implemented (i.e., all of the case companies focus on local territories for CSR development), while other pressures are conflicting; institutional conflicts bring to the forefront the relevance of managerial choices, resulting in heterogeneous strategies (i.e., diversified ways of balancing CSR objectives and industrial ones).

\section{Introduction}

The importance given to Corporate Social Responsibility (CSR) in research and practice has grown over time in line with the progressive recognition of its strategic role (Porter \& Kramer, 2006, 2011). In many organizations, CSR has become an essential element of the core business and is used to create long-term value thanks to improved reputation, investor attractiveness, innovation, process efficiency, and employee satisfaction (Moon, 2007). This increase in CSR strategic relevance has gone in parallel with the enlargement and the diversification of the set of practices that companies may enact in order to address the impact of their business on the environment and the society, such as community involvement initiatives, development of socially and environmentally responsible products and processes, socially responsible employee relations, sustainable reporting initiatives (Beschorner \& Hajduk, 2017).

How companies steer among different practices and give diverse emphasis to various social and environmental activities is influenced by the institutional context in which they compete, which informs the expectations of their stakeholders (Moratis, 2016). Indeed, since the first formulation of the concept of CSR in the 1950s, scholars have pinpointed the fundamental link between CSR practices and institutional pressures, as CSR was related to "those lines of action which are desirable in terms of the objectives and value of our society" (Bowen, 1953, p. 6) and as organizations must be considered legitimate by the surrounding world to survive on the long run (Scott, 1995). This intimate relationship also remained central 
in subsequent definitions despite the numerous modifications and evolution of the concept of CSR, and, recently, it was even further reinforced by the erosion of the clear distinction between business and government and the consequent increase in the expectations of civil society actors on corporations (Brammer, Jackson \& Matten, 2012; Scherer \& Palazzo, 2011). More than in the past, companies are considered not as "pure economic" actors but as "political" actors that are socially embedded within a wider field of social networks, business associations and political rules, and they are expected to determine certain results in terms of employment, consumption, environmental quality, and reduction social of inequality.

This view, however, does not entail a purely "responsive" role of companies, which is defined completely by exogenous expectations. Additionally, companies are expected to be innovative and agile to changes in their sustainability strategies, especially when there is space to address those changes by reacting with different options (Melkonyana, Gottschalkb \& Kamath, 2017). In particular, when designing their CSR strategies and deciding which practices to implement among many different alternatives, companies must understand and balance multiple institutional logics (Arena, Azzone \& Mapelli, 2018; Marano \& Kostova, 2016). The logics bring concurrent pressures as companies must consider, at the same time, the expectations deriving from all their relevant stakeholders, such as shareholders, governments, communities, customers, employees, suppliers and business partners. Furthermore, different logics are not independent, but interact and can either amplify or contrast one the other's effects (Arena et al., 2018; Marano \& Kostova, 2016). The must simultaneously address these multiple logics and reconcile contrasting ones, bringing to the forefront the role of companies in evaluating and choosing whose expectations to prioritize and how to answer them. That is, the simultaneous combination of multiple logics results in higher complexity and opens up spaces for managerial action from which diversity in CSR strategies stems.

Moving from these considerations, this paper intends to contribute to the understanding of how institutional dynamics inform companies' CSR strategies, both constraining companies by requiring the implementation of certain practices and promoting diverse strategies. In this respect, this paper aims generally to study managerial actions in terms of CSR strategies within a certain institutional context and, to reach that goal, it has a twofold objective. As a first step necessary to move to the second objective, this paper aims to study a specific industry sector - the utilities sector - providing a picture of the interplay of different institutional logics in this particular context. Second, this paper aims to analyse how institutional dynamics open up spaces for managerial actions, leading in the end to the rise of diverse CSR strategies in utility companies, thus helping to fill the gap identified in the literature (Arena et al., 2018; Marano \& Kostova, 2016; Melkonyana et al., 2017).

This paper is empirically based on qualitative data collected from three Italian organizations operating in the utilities sector. Utilities are entities that undertake public goods management, especially in the final stages of the supply chain, and include services such as production and distribution of electricity, distribution of gas, management of waste, water and even telecommunication (UNSD, 2018). The authors selected the utilities 
sector as an empirical setting since it has been characterized by growing sustainability issues, as shown in the following sections. Drawing on the framework proposed by Arena et al. (2018), which is based on an institutional perspective, the comparative analysis sheds light on how multiple logics create space for diversity to emerge in the practices adopted by the case companies and on how companies weight and balance multiple institutional pressures defining CSR strategic guidelines.

Therefore, this paper contributes to the stream of research proposing institutional logics as an adequate approach to studying heterogeneous CSR behaviours of companies even though they are in similar institutional contexts. Furthermore, these insights are also relevant by a practitioners' perspective as managers might benefit from an overview of logics impinging on CSR evolution and might improve their understanding of the CSR evolutionary dynamics, by clarifying the nature of the concurrent pressures companies might experience.

The remainder of this paper is organized as follows. In Section 2, the research framework is introduced. In Section 3, the methodology for case selection, data collection, and data analysis is covered. Section 4 presents the findings obtained from the cases. Finally, a discussion of the results is presented together with some suggestions for further studies in Section 5.

\section{Research framework}

To study how the interplay of multiple institutional pressures informs companies' CSR strategies in the utilities sector, this paper relies on the framework proposed by Arena et al. (2018). The framework starts from the premises that when an organization defines its CSR strategy, it needs to unravel the connection between the institutional pressures that shape the social obligations it is subject to and the characteristics of the CSR activities it may put in place. To support this aim, the framework identifies the dimensions along which CSR is evolving and the contextual factors that influence companies' choices with respect to CSR strategies, and explains how different institutional pressures can inform companies' positioning in relation to different CSR dimensions.

Based on a review of the literature in the field of CSR, Arena et al. (2018) identify five elemental categories, or dimensions, that can be used to depict the transformation of CSR strategies. The first elemental category is the balancing and relationships between CSR objectives, which refers to the relative weight a company attributes to economic, environmental and social goals and how they influence each other (Porter \& Kramer, 2006; Visser, 2012; Hahn \& Figge, 2016). The second elemental category is system boundaries, which consists of the geographical and time horizon over which the impacts of a company's activity are evaluated (Ny, MacDonald, Broman, Yamamoto \& Robért, 2006; Hahn \& Figge, 2016; Wu, Subramanian, Abdulrahman, Liu \& Pawar, 2017). Third, there is stakeholder engagement, which refers to those practices an organization undertakes to involve stakeholders in its activities (Greenwood, 2007; Athanasopoulou \& Selsky, 2015). The 
fourth is collaborations and alliances that consist of different forms of partnerships with external organizations, such as university and educational entities, international development organizations and associations, NGOs, and start-ups (Jamali \& Keshishian, 2009; Spitzeck, Boechat \& Leão, 2013). The last dimension is accounting and reporting, which refers to the set of instruments and methods used by a company for measuring and reporting its results in terms of economic, environmental and social performance (Fortanier, Kolk \& Pinkse, 2011; Junior, Best \& Cotter, 2014; Nikolaou \& Matrakoukas, 2016). Concerning the analysis of the contextual factors, Arena et al. (2018) draw on the concept of institutional logics (Friedland \& Alford, 1991; Thornton, 2004), intended as the underlying governing principles of some central institutions that influence means and ends of both individuals' and organizations' behaviours. In detail, moving from the central institutions identified by Thornton and colleagues (Thornton, 2004; Thornton, Ocasio \& Lounsbury, 2012), Arena et al. (2018) focus on four institutional logics that are considered particularly relevant in the field of CSR strategies: the market, the state, the community, and the professional logic.

They then discuss how the CSR elemental categories are influenced by these institutional logics, using the analytical instrument of the ideal type. An ideal type is a typology, represented through a matrix, where the $\mathrm{X}$-axis reports the institutional logics relevant in the context of CSR strategies and the Y-axis reports the CSR elemental categories. The combination of the institutional logics and the elemental categories provides a representation of the expected "behaviour" of the organization under the pressure of a specific institutional logic (see Table 1).

Table 1: Expected "behaviours" of organizations in terms of CSR elemental categories under the pressure of institutional logics (Arena et al., 2018)

\begin{tabular}{|l|l|l|l|l|}
\hline & Market & State & Community & Profession \\
\hline $\begin{array}{l}\text { Balancing and } \\
\text { relationships } \\
\text { objectives }\end{array}$ & $\begin{array}{l}\text { Profit maximization } \\
\text { and instrumental } \\
\text { approach }\end{array}$ & $\begin{array}{l}\text { No prioritization } \\
\text { Respect of relevant } \\
\text { laws and regulation } \\
\text { Focus on } \\
\text { contribution to } \\
\text { public good }\end{array}$ & $\begin{array}{l}\text { No prioritization } \\
\text { Focus on the impact } \\
\text { on the (local) } \\
\text { communities }\end{array}$ & $\begin{array}{l}\text { Shared value and } \\
\text { Triple Bottom Line } \\
\text { No trade-offs and } \\
\text { tensions }\end{array}$ \\
\hline $\begin{array}{l}\text { System } \\
\text { boundaries }\end{array}$ & $\begin{array}{l}\text { System boundaries } \\
\text { are set by the } \\
\text { company's } \\
\text { operations and its } \\
\text { reference market }\end{array}$ & $\begin{array}{l}\text { System boundaries } \\
\text { are set by the } \\
\text { countries / areas } \\
\text { where the company } \\
\text { operates }\end{array}$ & $\begin{array}{l}\text { Geographical } \\
\text { boundaries and/or } \\
\text { common activities } \\
\text { and beliefs }\end{array}$ & $\begin{array}{l}\text { System boundaries } \\
\text { concepts of } \\
\text { extended value } \\
\text { chain and lifecycle }\end{array}$ \\
\hline
\end{tabular}




\begin{tabular}{|l|l|l|l|l|}
\hline $\begin{array}{l}\text { Stakeholder } \\
\text { engagement }\end{array}$ & $\begin{array}{l}\text { Selected } \\
\text { stakeholders (in } \\
\text { particular the } \\
\text { powerful ones) with } \\
\text { the aim of furthering } \\
\text { the goals of the } \\
\text { organization }\end{array}$ & $\begin{array}{l}\text { stakeholders } \\
\text { stimate }\end{array}$ & $\begin{array}{l}\text { Interested } \\
\text { communities } \\
\text { (without } \\
\text { differentiation } \\
\text { between legitimate / } \\
\text { non-legitimate, } \\
\text { powerful / non- } \\
\text { powerful) }\end{array}$ & $\begin{array}{l}\text { Legitimate and } \\
\text { powerful } \\
\text { stakeholders }\end{array}$ \\
\hline and alliances & $\begin{array}{l}\text { Sollaborations and } \\
\text { alliances }\end{array}$ & $\begin{array}{l}\text { No specific } \\
\text { requirements }\end{array}$ & $\begin{array}{l}\text { Collaborations and } \\
\text { alliances with actors } \\
\text { involved in the } \\
\text { community }\end{array}$ & $\begin{array}{l}\text { Collaborations and } \\
\text { alliances with other } \\
\text { actors affiliated to } \\
\text { the "professional" } \\
\text { network }\end{array}$ \\
\hline $\begin{array}{l}\text { Accountability } \\
\text { and reporting }\end{array}$ & $\begin{array}{l}\text { Legitimacy and } \\
\text { reputation } \\
\text { management }\end{array}$ & $\begin{array}{l}\text { Compliance with } \\
\text { mandatory } \\
\text { disclosures }\end{array}$ & $\begin{array}{l}\text { Monitoring of issues } \\
\text { that are relevant to } \\
\text { the community }\end{array}$ & $\begin{array}{l}\text { Compliance with } \\
\text { standards and best } \\
\text { practices (GRI } \\
\text { reporting) }\end{array}$ \\
\hline
\end{tabular}

1

As follows, we briefly summarize the expected behaviour as discussed in Arena et al. (2018). Moving from the first elemental category, the balance and the relationship between objectives, the market logic drives the balance towards profit maximization and socio-environmental objectives are seen as instrumental for the economic ones (Carroll \& Shabana, 2010; Gao \& Bansal, 2013). The state logic simply assumes compliance with norms and regulations concerning social and environmental impacts (Buhmann, 2006). The community logic shifts the balance towards the interests of local communities. Finally, the professional logic stems from the guidelines provided by several professional associations and relies heavily on concepts such as shared value (Porter \& Kramer, 2006), and triple bottom line (McWilliams, Parhankangas, Coupet, Welch \& Barnum, 2016), which assume the lack of a prioritization between environmental, social and economic objectives and even denying tensions and trade-offs between them (Crane, Palazzo, Spence \& Matten, 2014).

Concerning the second CSR dimension, system boundaries, the market logic prompts a company to set its boundaries according to its reference market and its expectations. The state logic stresses the boundaries in terms of jurisdictional boundaries - i.e., the countries where the company directly operates. The community logic tends to set the boundaries according to the geographical positioning of the reference communities and to their interests and beliefs (Wu et al., 2017), while the professional logic tends to stress concepts such as extended value chain or lifecycle and the need for balancing stakeholders' legitimacy and power (UNIDO - 
United Nations Industrial Development Organization, 2009; ISO - International Organization for

2 Standardization, 2017).

The third CSR dimension is stakeholder engagement. Under the market perspective, stakeholders to be engaged must be strategically selected, as they are viewed as leverage to further economic interests. The state logic puts particular attention on legitimate stakeholders, those the company is related to either by a contract or by a moral relation (Fortanier et al., 2011). The professional logic emphasizes the involvement of those stakeholders that balance legitimacy and power (ISO, 2018; UNIDO, 2009). Finally, the community logic stresses the relevance of the relation between the company and the members of the communities affected by the company itself (Kumara, Gunasekaranb, Singha, Papadopoulosc \& Dubeyd, 2015).

The fourth CSR dimension is collaborations and alliances. Again, the market logic makes an organization focus on those actors that can further a company's profit, again with an instrumental view and to increase legitimacy (Currall and Inkpen, 2002), especially in local contexts (Spitzeck et al., 2013). The community logic envisages collaborations and alliances as naturally pursued with those entities that are connected with the community itself, such as local associations. Professional logic fosters collaborations and alliances with actors from related professional networks.

Finally, moving to the last dimension of CSR, the market logic relates socio-environmental accounting and reporting to firms' reputation, as it could serve as a tool to manage those stakeholders who have power over the company, such as socially responsible investors (Nikolaou \& Matrakoukas, 2016). Within the state logic, companies must comply with legal requirements. Additionally, the community logic stresses the need for monitoring and accounting sustainability issues that are relevant to the local communities in which the company is embedded (Reed, Fraser \& Dougill, 2006; Riley, 2001). Finally, the influence of professional logic is clearly depicted by reporting standards, such as the ones proposed by the Global Reporting Initiative (Fuente, García-Sanchez \& Lozano, 2017; GRI, 2018), the integrated reporting framework (IIRC, 2018), and their assurance standards (IFAC, 2018; AA1000, 2008).

A fundamental aspect that lies at the heart of the concept of institutional logics is that all central institutions contemporarily influence the organization, exerting concurrent pressures (Greenwood, Raynard, Kodeih, Micelotta \& Lounsbury, 2011). Hence, a company is simultaneously embedded in multiple institutional logics, facing institutional complexity (Marano \& Kostova, 2016). Such complexity is further amplified by the fact that different logics are not independent but rather interact with each other (Marano \& Kostova, 2016). In particular, those logics that have similar underlying values can reinforce each other, generating an amplifying effect (Lee \& Lounsbury, 2015). Instead, when different logics have contrasting underlying values, they generate tensions and contradictions that must be reconciled, bringing to the forefront the role of companies in evaluating and deciding what pressures to prioritize and how to answer them (Moratis, 2016), which could lead to the adoption of different strategies to respond to tensions (Arena et al., 2018). This interplay between 
the institutional pressures and the actor (either an organization or an individual) is a peculiar aspect that distinguishes the conceptual approach of the institutional logics from other streams in the institutional theory. Indeed, the influence of any of the central institutions on an organization's behaviour is "weighted" by the actors being affected by multiple institutional pressures (Thornton \& Ocasio, 1999). That is, the simultaneous combination of multiple logics results opens up spaces for managerial action, from where diversity stems.

However, even though how the institutional space created is filled by managerial choices has been already investigated in the literature, some gaps are still present as reported in the following (Arena et al., 2018). For instance, although Aguilera, Rupp, Williams and Ganapathi (2007) explored how groups of actors might influence CSR by following certain paths to legitimate their action, Powell and Colyvas (2008) argued for further studies on organizational actions (i.e., group actions), focusing in particular on how standards of legitimacy inform group practice in the society. Furthermore, Jamali and Neville (2011) show that multinational corporations' CSR programmes rest on global corporate discretionary decisions that are aimed at increasing their legitimacy in the eyes of local stakeholders but argue for contextualized studies. Nevertheless, more recently, Damayanthi \& Gooneratne (2017) study organizational actors, with a focus on management control, that must manage multiple external logics and argue for future studies to clarify how these logics influence internal processes.

(1)

To study the interplay of different institutional logics in informing CSR strategies a qualitative research method was adopted, which allows for an in-depth analysis of complex contexts (Eisenhardt, 1989; Lindgreen, 2008; Yin, 1994). In the following paragraphs, the process of case selection, data collection, and the techniques used to analyse data are presented.

\subsection{Empirical setting and case selection}

The empirical setting is represented by the utilities industry sector. In particular, the case companies are selected from the Italian context. Regarding the diffusion of CSR in Italy, it can be argued that even though CSR is expected to be at an advanced level of development due to the country's history (i.e., long tradition of entrepreneurs committed to philanthropy) (Harjoto \& Rossi, 2019), it appears to be not completely developed yet, especially referring to the endorsement of international CSR schemes. Indeed, several studies rank Italy after other EU and non-EU countries in CSR comparison (Halkos \& Skouloudis, 2017; Skouloudis, Isaac \& Evaggelinos, 2016). Also, in the European countries, CSR committees in corporations are diffusing even though it is mainly due to the influence of mandatory non-financial disclosure (Gennari \& Salvioni, 2018). Hence, it could be interesting to study the condition of CSR in Italy especially under the lens of 
institutional logics. Further, the paper is focused on the utilities sector as this industry appeared particularly interesting for the purposes of this study for two reasons. First, in recent years, the utilities sector has been under scrutiny for its social and environmental impacts (Frijn, Hofman \& Nederlof, 2013; IEA, 2018). The services that are provided by these organizations (energy, waste and water management) are often associated with environmental problems, such as emissions, pollution, consumption of resources, and land utilization; companies are expected to take on responsibility for the consequences that these issues can have on the well-being and the comfort of the local communities where they operate. This situation naturally makes sustainability and CSR a relevant part of the corporate strategy of these organizations, both in terms of opportunities that can be captured, such as the introduction of green technologies, and in terms of reputational risk.

Second, at least in Italy, some of the segments that characterize the energy market most significantly have undertaken relevant changes in recent decades in terms of a progressive process of liberalization started in 1999 and concluded in 2007. Originally, the electricity market was completely controlled by a large stateowned company but, starting from 1999, the various activities of the supply chain have been separated and assigned to different entities. Hence, after the liberalization process, several companies were created to compete on the market in the electrical power generation and electricity trade sectors. Despite this process of liberalization, utility companies provide services that are at least partly of a public nature. This has some important implications in terms of the market mechanisms governing the provision of the service itself. First, electricity prices are still partially regulated by State agencies. Second, to receive the right to provide the service, utility companies must participate in public tenders, and if they win the competition, they can sell service to citizens who pay taxes to the local entity for that service. This specificity is also reflected in the governance structure of these companies, which are often at least partly owned by the same public administrations that benefit from the service.

To study how the interplay of different institutional logics inform CSR strategies, we selected three of the biggest multi-utility companies in Italy (for confidentiality reasons, as follows, the companies are named Blue, White and Red).

Blue is a utility company operating in the North of Italy and, through a subsidiary, in other European countries. The company was founded in 2008 following the liberalization of the Italian market. It is listed on the Italian Stock Exchange and is 50\% controlled by the two largest Italian local entities (private shareholders own the rest of the shares). It has more than 13.000 employees and revenues are over 5 billion euros. Blue operates in the sectors of power generation, distribution and trading, heating power generation and distribution, water and waste management. Globally, in 2016, it produced over 13.000 GWh of electricity, and around one third of the electricity generated comes from renewable sources. 
White mainly operates in the Central regions of the country. It was founded at the beginning of 2000 and is listed on the Italian Stock Exchange. It is $51 \%$ controlled by the local municipality, while the remaining shareholders are private. It has approximately 7,000 employees and, in 2016, its revenues were nearly 3 billion euros. It operates in heating and electrical power production, distribution and trading, water and waste management. Recently, White has undertaken a deep transformation by significantly investing in a major digital integration. In 2016, it produced over 700 GWh of electricity, of which more than $70 \%$ comes from renewable sources.

Red is a utility company competing mainly in the North of Italy. It was funded in 2010 from the merger of several local municipalized companies; it is listed on the Italian Stock Exchange and it is more than 50\% controlled by the municipalities of the three cities where it is present. It employees more than 6,000 people, and it achieved 3 billion euros in revenue in 2016. Red operates in the sectors of electricity and heating energy production, electricity trading distribution, district heating, water and waste management services. In 2016, it produced over 9.000 GWh of electricity, approximately $70 \%$ of which came from renewables.

\subsection{Collection of materials and analysis}

Data collection was carried out combining semi-structured interviews with indirect sources to achieve a detailed picture of the case studies while limiting potential informant biases (Eisenhardt, 1989; Yin, 1994). Concerning indirect sources, we collected and examined documents produced by the companies themselves, including sustainability and annual reports of the last three years, press releases of the last three years, reports produced by third agencies, and internal documents provided by the informants (internal presentations, organizational manuals, internal performance reports). Concerning direct sources, we conducted 27 semi-structured interviews with 18 informants overall, and we took part in several public and private meetings organized by the companies concerning their sustainability and CSR strategies and the integration of CSR objectives in strategic planning processes.

For all the analysed companies, the head of the CSR/sustainability team was interviewed as a first informant, and the first interview was followed by follow-ups with one or more members of the CSR/sustainability team. Then, informants from other organizational units were interviewed, including representatives of the top management, informants from the organizational units up to strategy development, risk management or enterprise risk management, human resources, internal audit or management control.

In Table 2, a list of the informants is provided. All the interviews have been carried out between January 2015 and February 2017. Prior to interviews, information on the three companies was collected from public sources. Then, all interviews were carried out on the premises of the studied organizations. The interviews were carried out based on an interview protocol that was developed from the theoretical framework presented above and used with flexibility, enriching it when relevant topics emerged during the data 
collection. On average, the interviews lasted between one and two hours. All the interviews were recorded, except for one of them in which the informant did not allow recording; recordings were transcribed and additional materials (e.g., unpublished reports, internal presentations) provided by the informants were analysed.

Table 2: List of informants sub-divided by company and interview date

\begin{tabular}{|c|c|c|c|c|}
\hline $\begin{array}{c}\text { Case } \\
\text { company }\end{array}$ & $\begin{array}{c}\text { Revenues } \\
\text { (Euros) }\end{array}$ & $\begin{array}{c}\text { Electrical } \\
\text { energy } \\
\text { produced } \\
\text { (Gwh) }\end{array}$ & Interviewees & $\begin{array}{l}\text { Number of } \\
\text { interviews }\end{array}$ \\
\hline \multirow{7}{*}{ Blue } & \multirow{7}{*}{5 billion } & \multirow{7}{*}{13.000} & Head of CSR & 2 \\
\hline & & & Member of CSR unit & 1 \\
\hline & & & Head of Strategic Planning & 1 \\
\hline & & & Head of Enterprise Risk Management & 1 \\
\hline & & & Member of Enterprise Risk Management unit & 1 \\
\hline & & & Member of Enterprise Risk Management unit & 1 \\
\hline & & & Head of Smart City project & 1 \\
\hline \multirow{4}{*}{ White } & \multirow{4}{*}{3 billion } & \multirow{4}{*}{700} & Head of CSR & 2 \\
\hline & & & Head of Risk Management & 1 \\
\hline & & & Head of Human Resources & 1 \\
\hline & & & Member of Human Resources unit & 1 \\
\hline \multirow{7}{*}{ Red } & \multirow{7}{*}{3 billion } & \multirow{7}{*}{9.000} & Head of CSR & 3 \\
\hline & & & Head of Risk Management & 3 \\
\hline & & & Vice president & 1 \\
\hline & & & Member of Board of Directors & 1 \\
\hline & & & Head of Management Control & 4 \\
\hline & & & Head of Internal Audit & 1 \\
\hline & & & Head of Strategic Development & 1 \\
\hline
\end{tabular}

8 The data collected were analysed with the support of NVivo 10, a CADQUAS (Computer Assisted Qualitative 9 Data Analysis Software) developed to facilitate researchers in textual data analyses (Amaeshi, Adegbite \& Rajwani, 2016; del Mar Miras-Rodríguez, Carrasco-Gallego \& Escobar-Pérez, 2015; Hogarth, Hutchinson \& 
Scaife, 2016). All the scripts were imported in NVivo 10 to create an ordered database where each script was classified according to the company and the role of the informant. Then, the authors created an ad hoc coding system, articulated on two levels in order to highlight the connections between CSR items and institutional pressures. The first level coding concerned the CSR items identified by the framework proposed by Arena et al. (2018). The second level coding concerned the institutional logics and related aspects (i.e., market, community, profession, state). The intersections of the two coding levels allowed for isolating the quotes significant to create an interpretive model to answer the research questions and build on existing theory.

\section{CSR strategies in the case settings}

In the following, the results are presented, with a discussion of how and why the selected organizations have configured their CSR strategies in connection with the five elemental categories previously discussed. Companies' approach to CSR is illustrated focusing on those elements that are peculiar to the single case or to the industry.

Blue

The issue of CSR is considered central to the company's strategy, with great emphasis placed on the need to integrate socio-environmental and economic goals, as emerges from several quotes of the strategic plan:

"Our future is sustainable, green, open, smart". (2017 Blue Strategic plan)

and to support this growth the company is planning to spend:

" $40 \%$ of CAPEX in sustainability" and "to increase the share of electricity customers that buy green energy up to 90\%". (2017 Blue Strategic plan)

This push towards integration appears to be driven mainly by an instrumental view of CSR, informed by market logic. This is visible at two different levels. First, the company is placing increasing attention on using environmentally friendly technologies in the provision of traditional services (water and waste management) and increasing the quota of renewable sources in connection to energy services. In this way, Blue is aiming to create win-win conditions for both shareholders and local stakeholders (i.e., territorial communities), improving the services provided in terms of efficiency and quality, and benefiting the local communities by reducing the environmental burden. Second, the company is increasingly developing projects connected to four pillars - circular economy, decarbonisation process, smart systems and services, and people innovation that represent new business opportunities, and, at the same time, bring a positive environmental impact. These projects are integral to the company's 2020 Sustainability Plan and the 2030 Sustainability Policy, which have been developed through the involvement of CSR managers, strategy development managers and business unit managers. 
"We have organized two workshops during which the top managers gathered to reflect together on the topics on which Blue can work in terms of sustainability, moving from the SDGs. We have begun our work from the 17 SDGs from the UN." (Blue, Head of CSR)

"The top managers have defined directions in terms of sustainability. [...] Then, the managers of the different business units, with their staff, have defined numerical objectives in line with these directions." (Blue, Head of Strategic Development)

The relevance of CSR from a strategic perspective also emerges from the shift that took place recently from an ex-post approach (based on the measurement of the environmental and social performance) to an exante approach, where sustainability objectives are planned in advance, such as business objectives, and monitored afterwards. This again suggests the relevance of the market logic in informing the way a company addresses sustainability objectives, further reinforced by professional logic in fostering the development of the technical tools that are used to formalize the objectives.

"When the new top management arrived, new CEO and President... They introduced a significant boost to sustainability topics. From that moment, we shifted from an ex-post approach to planning directives." (Blue, Head of Strategic Development)

"Considering the kind of activities we have [...], sustainability was already integrated in the business, due to the services we offer to citizens; we have now realized that is also necessary to plan it." (Blue, Member of CSR unit)

In terms of boundaries, the interviews pinpointed high attention to the local dimension, which is identified as the municipal area where the company is responsible for the provision of the service. The citizens of the municipality are the clients of the service, and so they must be satisfied with the service provided. At the same time, they represent the local community in a broader sense, and they should be made aware of the contribution of the company to the development of the territory.

"[Concerning CSR] we have added to the plan two key issues. [...] One of those was to increase our presence on the territories." (Blue, Head of Strategic Development)

"Still today, when we must define innovative solutions, even from a technological point of view, we need the territory to accept our proposals; we cannot avoid that." (Blue, Member of Enterprise Risk Management unit)

From this perspective, the market logic and the community logic push the company into the same direction, defining the company's spatial boundaries based on the borders of the municipalities the company serves. On the other hand, when considering time boundaries, meaning time horizons, the market logic pushes the company to align sustainability goals with industrial goals (i.e., 2022 strategic plan and 2020 sustainability plan), while the community logic extends the time span. Local stakeholders ask Blue for long-term projects, and even though Blue would prefer to select those projects that can be realized on a short-medium time 
horizon, where feasible for the company, it also implements long-term projects proposed by the stakeholders, embracing hybrid solutions:

"We also had some other projects over the long term, such as the idea coming from local stakeholder of using heating district system for cooling to avoid the necessity of air-conditioning appliances in private houses. Thus, Blue accepted the proposal, commissioned some studies and now it is implementing the project, starting from public buildings but the idea is to enlarge it." (Blue, Head of (SR)

The extension of the time span is also reflected in the requests put forth by the Territorial Committee of defining a Sustainability Policy for 2030, which complements the medium-term sustainability plan to 2020 where emphasis is put on long-term objectives and their linkage with the SDGs:

"the analysis of the relevance of the 17 SDGS in comparison with Blue value chain" (Blue, Sustainability policy)

The interplay of the market and community logic also emerges in connection with stakeholder engagement processes. Concerning this issue, Blue has adopted the instrument of multi-stakeholder forums in order to identify projects of interest in the local community where it operates. Multi-stakeholder forums are round tables to which Blue invites representatives of the local communities, who are then asked to highlight issues that affect the reference territory and ideas for future projects to address these issues. Some of the ideas are then selected and implemented by the company. The informants declare that the aspiration of these multistakeholder forums is

"to listen not to single stakeholders, but to multiple stakeholders, hence all the stakeholders present on a specific territorial area" (Blue, Member of CSR unit)

as they aim to build and maintain a dialogue with the territories. An example of a project born thanks to the interaction with stakeholders through the multi-stakeholder forums is the "Bank of Energy", which allows those families to be provided with energy that are no longer able to pay for it due to economic constraints. The project aims to collect funds from Blue customers, who pay a small amount each month to the company through the normal bill to support these families. For each euro collected from the customers, both an Italian foundation and Blue subsidise those families with other money by providing them with energy and other services to reduce the poverty condition in which they live. It is clear that by doing this Blue is able to answer both to community pressure and market pressure, as it meets communities' requirements by subsidizing this initiative but at the same time it is able to enlarge its own business.

The partnership of Blue with the Italian foundation involved in "Bank of Energy" also leads to the elemental category of collaborations and alliances. With this regard, Blue is deeply influenced by the community logic, as it adopts partnerships merely in connection with specific projects aimed at bringing benefits to the communities. 
"[Referring to the presence of collaborations and alliances in Blue] to reach the fixed objectives, I wouldn't say there are. [...] But there are some specific cases, such as the "Bank of Energy", in which it is clear that we need to collaborate with [name of the Italian foundation] and also with all the associations that will be selected at the local level to bring funds to the families in need." (Blue, Head of CSR unit)

Finally, moving to the last elemental category, accounting and reporting, the influence of multiple logics can be recognized. The state logic has played a fundamental influence, especially in terms of environmental reporting, as highlighted by the following quote:

"Considering the environmental aspects, all our plants have certifications and are compliant with national and international regulations; hence, they have already implemented an advanced reporting system." (Blue, Member of CSR unit)

Since the beginning, Blue has been highly compliant with international standards for sustainability reporting. Since 2008, it adopted the Global Reporting Initiative standards and, more recently, it has shifted to the integrated reporting partly as a result of the influence of professional groups and partly in the attempt of attracting green investors, who are considered more interested in this form of reporting:

"The sustainability report is actually evolving towards an integrated report, and hence towards the logic of communication for the financial community." (Blue, Head of CSR)

On the other hand, community logics drive companies to report sustainability performances in a way that could be of interest and easily comprehended by non-specialized audience.

"[Referring to sustainability reports] they are essential documents for investors and professionals but communicating the idea of CSR to territorial stakeholders is even somehow more challenging. [...] The territorial sustainability reports were born from the necessity to establish a dialogue with single territories, as we realized that often local stakeholders, while reading Group sustainability reports, asked us 'What do you actually do for us?" (Blue, Head of CSR)

Under the pressures of these divergent logics, Blue adopted a decoupling strategy, splitting CSR reporting into two sets of documents: they produce an integrated report to disclose information for the financial community (market and professional logics), and a number of ad hoc sustainability reports addressing the communities on the territories (community logic).

A synthesis of the analysis carried out above is reported in Table 3. 
Table 3: Blue CSR strategies

\begin{tabular}{|l|l|l|l|l|}
\hline Blue & Market & State & Community & Profession \\
\hline $\begin{array}{l}\text { Balancing and relationships } \\
\text { between CSR objectives }\end{array}$ & Dominant & & $\begin{array}{l}\text { Synergic with the } \\
\text { market logic }\end{array}$ \\
\hline System boundaries & $\begin{array}{l}\text { Relevant and } \\
\text { synergic with the } \\
\text { community logic }\end{array}$ & $\begin{array}{l}\text { Relevant and } \\
\text { synergic with the } \\
\text { market logic }\end{array}$ & $\begin{array}{l}\text { Synergic with the } \\
\text { market logic }\end{array}$ \\
\hline Stakeholder engagement & $\begin{array}{l}\text { Relevant and } \\
\text { synergic with the } \\
\text { community logic }\end{array}$ & $\begin{array}{l}\text { Relevant and } \\
\text { synergic with the } \\
\text { market logic }\end{array}$ & \\
\hline $\begin{array}{l}\text { Collaborations and } \\
\text { alliances }\end{array}$ & $\begin{array}{l}\text { Relevant and } \\
\text { synergic with } \\
\text { reporting }\end{array}$ & Dominant & $\begin{array}{l}\text { Relevant but not } \\
\text { synergic with the } \\
\text { other logics }\end{array}$ & $\begin{array}{l}\text { Relevant and } \\
\text { synergic with } \\
\text { market logic }\end{array}$ \\
\hline Accountability and & & &
\end{tabular}

White

6 The second analysed company, White, is in a transition phase, which is well reflected in the way the company is configuring the five CSR elemental categories under the influence of mixed institutional logics. In defining the balance of objectives, White is strongly informed by the state logic as a result of the original public nature of the organization. During the interviews, the informants stressed the relevance of laws and regulations in defining the actions of the company as highlighted by the following quote:

"Companies operating in our industry are used to develop and implement proper tools to ensure the respect of laws and regulations. [...] The sector national authorities dictate performance indicators that are more and more challenging, year by year, or even with a longer time horizon, so that companies are driven not only to report to the authorities but also to enact virtuous dynamics." (White, Head of CSR)

The informants also appeared aware that the industry is experiencing a profound change, and highlighted several times during the interviews that "a process of change is taking place" and "the company is integrating sustainability in its business activities as a result of this changing environment" as shown by the following quotes: we work is enabling an accelerated process of change. So, over time, the behaviour of the company 
is changing and now it is even proactive and aware of the relevance of sustainability issues for the business of the company in itself. [...] Now, we are mainly working on the progressive integration of sustainability into our strategy." (White, Head of CSR)

"What we are trying to do regarding social responsibility, for the first time this year [2016], due to external pressures, is to define a sustainability plan for the whole Group." (White, Head of Risk Management)

The sustainability plan was developed with the same timing of the strategic plan and approved by the Board of Directors for the first time in 2016 , as underlined by the informants several times during the interviews. The sustainability plan emphasizes the integration of sustainability into business activities and the attempt of introducing an ex ante approach:

"the governance level is articulated on five themes that are aimed to enable the progressive integration of sustainability in the company's management" (White, 2016 sustainability report)

The sustainability objectives included in the sustainability plan were defined thanks to two focus groups with the top management. Through this process, five macro-goals were defined, i.e., to support the centrality of the customers, to value people during changing processes, to qualify territorial presence and protect the environment, to foster healthy and safety along the value chain and to invest in innovation for sustainability. Nevertheless, the linkage between business objectives and sustainability objectives appears more formal than substantial, driven by the will of "not remaining behind other companies" operating in the same industry. From this perspective, the practices implemented have been influenced by the confrontation with other companies that took place thanks to professional networks (professional logic).

Moving to system boundaries, similar to the case of Blue, White's focus is clearly on the local scale, on the municipal area where it works due to a combination of market and community logic.

"Utilities have a sort of natural propensity, which is intrinsic in their activities, to proactively interact with the territory, even listening to it, since they impact in such a deep way on territorial development... And also because they need to face territorial requirements. If not, they are not given the consensus to operate." (White, Head of CSR)

Concerning time span, White has designed its sustainability plan on a medium term (2018-2022) in line with the strategic plan; in particular, the interviewees stressed that they would have revised the sustainability objectives on an annual basis to be aligned with strategic planning.

"We have added sustainability objectives on the medium term, exactly with the same timing of the industrial plan." (White, Head of CSR)

Even in this case, particular attention is given to aligning the key dates of publication of the documents, but in terms of content, there is little evidence of actual integration. Hence, the alignment appears more formal 
than substantial, driven by the will of demonstrating that the company is similar to other companies operating the same field that are aligning strategic and sustainability planning. This can be explained with a process of contamination that took place in the professional circles in which the CSR manager is involved.

Concerning stakeholder engagement, White has also developed several activities for local stakeholders, such as sensitivity initiatives for students and work-life balance supportive initiatives for employees, especially for women. In addition, in 2015, White launched a call for proposals for innovative projects for a big Italian city.

Despite the significant attention to the local dimension, the initiatives addressing local stakeholders are often isolated as emerges from the following comment.

"To be honest, for now, these activities are very fragmented in the company, we don't yet have an action that is systematized and centralized. [...] I'm aware that [name of other companies] have already completed this step, we are now considering this option." (White, Head of CSR)

Moving to the elemental category of collaborations and alliances, White has some partnership with local associations and entities, such as schools, but the informants highlighted that these partnerships are not considered strategic.

"There are some initiatives that are carried out in partnership with local entities, but they are specific initiatives, maybe more social-oriented initiatives." (White, Head of CSR)

Finally, considering accounting and reporting, the influence of multiple logics is evident. White has been one of the first Italian companies to prepare a social report.

"Due to the effect of the external pressure, White has been a pioneer of social reporting, as we are at the $18^{\text {th }}$ year. [...] It was the same year when the company was listed on the stock exchange." (White, Head of CSR)

In the very beginning, White introduced social reporting adopting the guidelines proposed by a national institution, Fondazione Enrico Mattei. Then, when the GRI became the reference standard for sustainability reporting, the company adopted this framework. In this case, the interplay of the professional and the state logic is evident, as the informants highlighted the relevance of making reference to international standards and to be compliant with the requirements of the national authorities in terms of disclosures about environmental results.

"We began following the directions provided by Enrico Mattei Foundation. Then, since 2002, we began to adhere to the GRI, not only concerning the indicators but also with the assurance by an external agency, from the beginning every year. [...] The national authorities ask companies similar to White to put in practice very detailed monitoring systems for environmental performance." (White, Head of CSR) 
More recently, White has started a process to shift towards the integrated reporting under the influence of the professional logic, whereby this approach has been somehow recommended in professional networks and the implementation of the EU Directive on non-financial reporting.

"The external environment is trying to tell listed companies 'Be careful with the ultimate document addressing shareholders, we want it to include data not only concerning economic issues'." (White, Head of (SR)

Again, the influence of the market logic was somehow mediated by the professional logic. White began to think about integrated reporting because other companies operating in this industry started to move in this direction. Indeed, the latest sustainability reports appear to address a more specialized audience than a general one, since they present extended sets of quantitative and technical indicators.

"In 2011, the Committee of Ethics and Sustainability approved a document which made real the willingness expressed by the top management to publish together the sustainability report and the financial report. [...] It means that these two documents have now the same dignity." (White, Head of (SR)

The CSR strategy of White is synthesized in terms of CSR items and relevant institutional pressures in the following table (Table 4).

Table 4: White CSR strategies

\begin{tabular}{|c|c|c|c|c|}
\hline White & Market & State & Community & Profession \\
\hline $\begin{array}{l}\text { Balancing and } \\
\text { relationships between } \\
\text { CSR objectives }\end{array}$ & $\begin{array}{l}\text { Emerging, not } \\
\text { challenging the } \\
\text { dominant logic }\end{array}$ & Dominant & & $\begin{array}{l}\text { Emerging, not } \\
\text { challenging the } \\
\text { dominant logic }\end{array}$ \\
\hline System boundaries & $\begin{array}{l}\text { Emerging, not } \\
\text { challenging the } \\
\text { dominant logic }\end{array}$ & & Dominant & $\begin{array}{l}\text { Emerging, not } \\
\text { challenging the } \\
\text { dominant logic }\end{array}$ \\
\hline $\begin{array}{l}\text { Stakeholder } \\
\text { engagement }\end{array}$ & & & Dominant & \\
\hline $\begin{array}{l}\text { Collaborations and } \\
\text { alliances }\end{array}$ & & & Dominant & \\
\hline $\begin{array}{l}\text { Accountability and } \\
\text { reporting }\end{array}$ & $\begin{array}{l}\text { Emerging, not } \\
\text { challenging the } \\
\text { dominant logic }\end{array}$ & $\begin{array}{l}\text { Relevant and } \\
\text { synergic with the } \\
\text { professional logic }\end{array}$ & & $\begin{array}{l}\text { Relevant and } \\
\text { synergic with the } \\
\text { state logic }\end{array}$ \\
\hline
\end{tabular}

Red

Red has traditionally focused on the relationship with the local communities, paying particular attention to two aspects: ensuring access to its services, at the low prices, for all the citizens, and involving local 
communities through different stakeholder engagement mechanisms aimed mainly at educating them on issues such as energy and water efficiency.

"Red presents itself as a modern company that is able to create economic value, while protecting the environment and respecting stakeholders' expectations, and has set community and territory as a central point of its strategies [...]. The 2021 Industrial Plan shows the relevance attributed to local communities, including among the strategic directions the sustainable development of the territory." (2016 Sustainability report)

Recently, Red has also recognized that CSR could open up market opportunities. The company has embraced a process to move towards a major integration of sustainability objectives with industrial ones, identifying how the company can exploit potential synergies under the influence of the market and the community logics.
"We need to show what are the advantages of [...] CSR, meant as the ability to predict an event as an advantage for the company and, above all, within the decision-making process." (Red, Vice president)

"Above all for a company like Red, so deeply linked with the territory, from sustainability we could even obtain commercial benefits." (Red, Head of Management Control)

These synergies are underlined in key financial documents. For instance, the updated 2022 Industrial Plan reports several references to sustainability practices, including energy efficiency, sustainable mobility and smart grids, which are presented as a strong commitment of the company to meet communities' requirements and new market opportunities.

Considering system boundaries, Red shares with the other case companies a focus on the local dimension, as the community and the market logic tend to fix a company's boundaries in the local territories due to the intrinsic nature of the firm.
"In particular, the local media dedicate great attention to Red and it may bring risks in terms of reputation. Territorial committees [committees gathering local stakeholders] could help in this direction and they are also essential to improve services, in particular whenever they identify some malfunctions." (Red, Head of Internal Audit)

Concerning time span, Red has designed its sustainability plan on a medium-term horizon in line with the strategic plan, and has defined long-term sustainability objectives in the sustainability report, albeit mainly in qualitative terms. These objectives reflect the calls of local stakeholders, which are formulated through the so-called territorial committees. Territorial committees are presented as an innovative way to foster the dialogue between the firm and its local stakeholders (i.e., clients of the Municipalities that Red serves), where they can bring concerns and proposals to improve the services the company offers and to support local development. They allow the company to build a "deep and fair listening of local stakeholders' needs" (Red, 
2016 sustainability report). Red has also created an online platform to allow citizens to propose ideas, vote on already selected ideas and participate in discussions. In the informants' words, territorial committees aim to be:

"an open channel for continuous dialogue [...] as it is the committee itself that brings issues, projects or activities to be faced or to be realized" (Red, Head of CSR)

In this regard, market logic and community logic seem to be convergent in leading the company to invest in local stakeholders. It is worth noting that the stakeholder engagement system is similar to the one presented in the case of Blue, but Red was the first utility among the three case studies to develop this kind of approach to stakeholders.

Moving to the elemental category of collaborations and alliances, Red has been building partnerships with two main types of entities: local suppliers and local associations. Concerning the former, Red has developed an online portal to involve suppliers in strategic and sustainability initiatives and, in particular, it devotes considerable attention to local suppliers. Relevant services are provided by social cooperatives and social enterprises that operates in the municipalities served by Red, in line with the tradition of the company and closely related to the territory. Concerning the second type of partnerships, Red exploits local associations as a strategic channel to reach local stakeholders.

"Red also collaborates with institutions through financial support, working on specific projects that can be related to its mission and especially working on those projects that can contribute to economic, social and environmental sustainability of the reference territories." (2016 Sustainability report)

Both types of partnership are informed by a community logic, which the company leverages on the network of actors that share its geographical boundaries.

Finally, concerning accounting and reporting, Red began publishing sustainability reports from the first year of foundation using the GRI standards (professional logic); more recently, it started moving towards integrated reporting, mainly under the influence of the market and the professional logics. However, since local communities require more concise and simpler reporting than financial stakeholders (i.e., community logic), Red is working to decouple its reporting system. In particular, to disclose the information relevant for the local communities, specific reports are delivered, even though they are not actually formal ones.

"As an 'informal' reporting, after each meeting [of territorial committees], a report is published either on single projects under analysis or on general communications. All the minutes of territorial meetings are public and published on our website." (Red, Head of CSR)

The results of the study of Red CSR strategies are synthesized in Table 5. 
Table 5: Red CSR strategies

\begin{tabular}{|l|l|l|l|l|}
\hline Red & Market & State & Community & Profession \\
\hline $\begin{array}{l}\text { Balancing and } \\
\text { relationships between } \\
\text { CSR objectives }\end{array}$ & $\begin{array}{l}\text { Relevant. Partly } \\
\text { synergic and partly } \\
\text { conflicting. }\end{array}$ & & $\begin{array}{l}\text { Relevant. Partly } \\
\text { synergic and partly } \\
\text { conflicting. }\end{array}$ & \\
\hline System boundaries & $\begin{array}{l}\text { Relevant and synergic } \\
\text { with the community } \\
\text { logic }\end{array}$ & & $\begin{array}{l}\text { Relevant and synergic } \\
\text { with the market logic. }\end{array}$ & \\
\hline $\begin{array}{l}\text { Stakeholder } \\
\text { engagement }\end{array}$ & $\begin{array}{l}\text { Relevant and synergic } \\
\text { with the community } \\
\text { logic }\end{array}$ & & $\begin{array}{l}\text { Relevant and synergic } \\
\text { with the market logic }\end{array}$ & \\
\hline $\begin{array}{l}\text { Collaborations and } \\
\text { alliances }\end{array}$ & $\begin{array}{l}\text { Relevant and synergic } \\
\text { with the professional } \\
\text { loporting }\end{array}$ & & Dominant & Relevant but not \\
\hline Accountability and & synergic & $\begin{array}{l}\text { Relevant and } \\
\text { synergic with the } \\
\text { market logic }\end{array}$ \\
\hline
\end{tabular}

\section{Results}

The empirical analysis highlighted the relevance of the coexistence of different institutional pressures in informing the CSR strategies adopted by the analysed companies, providing insights to understand the commonalities and differences emerged in the three case settings. Commonalities are closely related to some specificities of the industry sector and can be well explained in light of the interplay of the market and the community logics. These logics drive the three companies towards a territorial focus in terms of spatial boundaries. The citizens of the municipalities served by the utilities represent to some extent both the customer base and the local community with whom the companies interact. From this perspective, the two logics reinforce each other, because the citizens must be provided with a service that is satisfactory from a market perspective (efficient and reliable), and at the same time it should be respectful of the environment and communities. In this way, the companies are pushed to look for business strategies, such as the usage of renewable sources and investments in green technologies, which allow them to improve both economic and environmental objectives.

The identification of the spatial boundaries is then reflected in the stakeholder engagement mechanisms that are developed by each company. In this respect, all the three companies have clearly identified local stakeholders as the subjects they must engage; they share similar aspirations in terms of type of engagement they have (or would like to) put in place even if a time lag can be highlighted between Red and Blue, on the one side, and White, on the other side. In particular, Red has been the first mover in the sector in the adoption 
of innovative mechanisms of stakeholder engagement. White is aware of the need to engage the local stakeholders but has begun moving in this direction only recently.

A further element of commonality is represented by the rational in the choice of the partnerships and alliances that were driven mainly by the community logic. In the three cases, collaborations and alliances are developed with actors that are part of the local community, such as local associations or institutions that are interested in or related to the local municipality. These collaborations are not considered strategic from a market perspective, and there is no evidence of the three companies selecting partners that are highly "competent" in a specific field, as the professional logic could suggest. Partners are selected because they operate in the territory and this feature can help the companies to relate even more tightly with the territories they serve.

On the other hand, the influence of the institutional logics is central for explaining the differences emerged from the case analysis, which can be related to the answers put in place by the organizations to respond to concurrent (and divergent) pressures. When tensions emerge between different pressures, the companies tended to answer with one of the following strategies: focusing on one prevailing logic; hybridizing practices in order to balance contrasting logics; and decoupling initiatives to answer "in parallel" to different pressures. This heterogeneity in the companies' answers is particularly evident concerning two related dimensions of CSR: the balancing of CSR objectives, and accounting and reporting.

Moving from the first issue, the case analysis shows how the three companies designed their strategies based on the logic that they felt to be prevailing (that is not the same in the three cases) even if the influence of all the four logics was present to some extent. In the case of Blue, CSR is used in an instrumental way, in order to take advantage of its "business case", as per the market logic. This is evident in the way the sustainability objectives have been integrated into the strategic objectives, with the clear aim of leveraging sustainability to grasp new market opportunities. The prevalence of the market logic is also evident in the way the company is starting to engage with responsible investors (developing the instruments that are more suitable to interact with this particular type of investors). Nevertheless, even in the selection process of the projects coming from multi-stakeholder forums, one of the criteria is that projects are supposed to be in line with the company's strategic goals. On the other hand, in the case of White, traditionally the leitmotif has been the compliance in the provision of a public service, suggesting the prevalence of a state logic. Limited attention has been given to the possibility of increasing the market share, by providing new services or employing new technologies, probably because the issue of market competition was not so urgent in this case. Indeed, the company has been pushed to adopt more challenging sustainability objectives by the influence of the regulators. Nonetheless, more recently, it appears that the company is moving towards a more marketoriented approach, probably due to the influence of its competitors' behaviour. Finally, in Red, the community and the market logic tend to be perceived as prevalent, leading to a solution that in the end appears to be a hybrid. Indeed, Red has defined sustainability objectives that can answer to the local 
territories' requirements and, at the same time, to improve the company's business, thus preferring win-win solutions. Furthermore, Red presents itself as a company able to create value both for the communities and for shareholders.

The different way of balancing CSR objectives is reflected in the companies programmatic and strategic documents. Blue has integrated the sustainability discourse in the industrial plan and has developed a medium- and long-term sustainability plan that is developed contextually to the industrial plan. White has a sustainability plan that is separate from the industrial plan even if there is a formal alignment (through aligned dates). In addition to the sustainability plan, a sustainability policy has been published and it mainly deals with qualitative goals. Red has begun integrating sustainability objectives in the industrial plan in addition to the formulation of mainly qualitative sustainability goals.

Considering accounting and reporting, companies' answers to divergent logics lead to decupling and hybrid answers. In this case, the market and professional logics drive the companies towards integrated reporting addressed to financial stakeholders, while the community logic drives the companies towards other simplified forms of reporting. In the case of Blue, the CSR unit has been pushed to produce ad hoc reports for the local communities to complement the Group integrated report, in Red informal reports for local communities are produced in addition to the sustainability integrated report, while in White no reporting systems for local communities have been developed.

The results presented in the above section are summarized in Table 6.

Table 6: Comparison of the CSR strategies of the three case companies

\begin{tabular}{|c|c|c|c|c|}
\hline Comparison & Market & State & Community & Profession \\
\hline $\begin{array}{l}\text { Balancing and } \\
\text { relationships between } \\
\text { CSR objectives }\end{array}$ & $\begin{array}{l}\text { Blue: market logic is } \\
\text { prevalent, and CSR is } \\
\text { used in an } \\
\text { instrumental way } \\
\text { Red: market logic is } \\
\text { prevalent with } \\
\text { community logic, a } \\
\text { hybrid approach for } \\
\text { CSR is adopted }\end{array}$ & $\begin{array}{l}\text { White: state logic is } \\
\text { prevalent and the } \\
\text { leitmotiv for CSR is } \\
\text { compliance with the } \\
\text { regulator }\end{array}$ & $\begin{array}{l}\text { Red: community } \\
\text { logic is prevalent } \\
\text { with market logic, a } \\
\text { hybrid approach for } \\
\text { CSR is adopted }\end{array}$ & \\
\hline System boundaries & $\begin{array}{l}\text { Market logic is } \\
\text { synergic with } \\
\text { community logic and } \\
\text { it drives all the case } \\
\text { companies to a }\end{array}$ & & $\begin{array}{l}\text { Community logic is } \\
\text { synergic with market } \\
\text { logic and it drives all } \\
\text { the case companies } \\
\text { to a territorial focus } \\
\text { on the local scale }\end{array}$ & \\
\hline
\end{tabular}




\begin{tabular}{|c|c|c|c|}
\hline & $\begin{array}{l}\text { territorial focus on } \\
\text { the local scale }\end{array}$ & & \\
\hline $\begin{array}{l}\text { Stakeholder } \\
\text { engagement }\end{array}$ & $\begin{array}{l}\text { Market logic is } \\
\text { synergic with } \\
\text { community logic and } \\
\text { it drives all the case } \\
\text { companies to } \\
\text { develop local } \\
\text { stakeholder } \\
\text { engagement } \\
\text { mechanisms }\end{array}$ & $\begin{array}{l}\text { Community logic is } \\
\text { synergic with market } \\
\text { logic and it drives all } \\
\text { the case companies } \\
\text { to develop local } \\
\text { stakeholder } \\
\text { engagement } \\
\text { mechanisms }\end{array}$ & \\
\hline $\begin{array}{l}\text { Collaborations and } \\
\text { alliances }\end{array}$ & & $\begin{array}{l}\text { Community logic is } \\
\text { dominant, and it } \\
\text { drives all the case } \\
\text { companies to } \\
\text { develop } \\
\text { collaborations and } \\
\text { alliances with actors } \\
\text { from the local } \\
\text { communities }\end{array}$ & \\
\hline $\begin{array}{l}\text { Accountability and } \\
\text { reporting }\end{array}$ & \multicolumn{3}{|c|}{$\begin{array}{l}\text { Logics are divergent: market and professional logics drive companies towards integrated } \\
\text { reporting for financial investors, while the community logic drives them towards simpler } \\
\text { forms of reporting, Hence, companies adopt different strategies. } \\
\text { Blue: in addition to the Group sustainability report, produces ad hoc sustainability reports for } \\
\text { local communities } \\
\text { Red: in addition to the Group sustainability report, produces informal sustainability reports } \\
\text { for local communities } \\
\text { White: produces the Group sustainability report and there is no reporting systems for local } \\
\text { communities }\end{array}$} \\
\hline
\end{tabular}

\section{Discussion and conclusions}

3 It can be argued that the comparison of the three companies offers a meaningful empirical setting to study

4 how institutional logics impinge on companies' CSR strategies and what their effects are on managerial

5 choices. In particular, besides the specific strategies adopted by the case companies, it is relevant to highlight

6 that both homogeneous and heterogeneous behaviours have been identified to respond to logics' dynamics.

7 These considerations might support the advancement of theoretical and practitioners' knowledge on CSR

8 strategies' development, as shown in the following. 
From a theoretical viewpoint, the paper contributes to the extant literature that proposes the institutional logics approach as a proper theoretical framework to study CSR (Greenwood et al., 2011; Thornton \& Ocasio, 1999; Young \& Makhija, 2014) by providing a picture of concurrent institutional logics in the utilities sector. Indeed, the paper is in line with the stream of research that posits institutional logics as a promising option to respond to the critiques to traditional institutional theory that is frequently criticized for relying too much on structural determinism in explanations (DiMaggio, 1988; Mouritsen, 1994). In particular, our results demonstrate that institutional logics' dynamics provide a relevant conceptual infrastructure to explain heterogeneity in organizations' behaviours even when they are in similar institutional contexts. This consideration reinforces also what Binder posits, claiming that organizations could "find heterodox ways of responding to the accountability demands of [their] environment" (Binder, 2007, pp. 567).

One of the reasons driving corporations is the need for legitimacy (Scott, 1995). Indeed, the results of the paper contribute to the stream of literature dealing with CSR as an approach to legitimize companies' business. In particular, this paper corroborates what Jamali and Neville (2011) posit, as it shows that corporations adapt their CSR approach to legitimize their action with local stakeholders by adopting a variegated set of strategies. Additionally, the paper responds to the need for research about the influence of legitimacy on organizational actors (Powell \& Colyvas, 2008).

Nevertheless, the empirical analysis might reinforce the literature addressing emerging tensions among logics in corporate sustainability by highlighting three strategies the case companies tend to adopt to respond to tensions, thus contributing to fill the gap highlighted by Hahn, Pinkse, Preuss \& Figge, 2015. Specifically, three different kinds of resolution strategies that could enable the companies to manage tensions proactively have been identified and they resonate also with Arena et al. (2018). Hence, this paper proposes criteria to develop CSR and sustainability strategies that also allow companies to design their own approach in a way that is in line with their peculiar configuration, thus contributing to fill the gap highlighted by Melkonyana et al. (2017). Finally, the paper enables the understanding of how managerial choices influence the decision of relying on one strategy instead of the others.

From a practitioners' viewpoint, the empirical analysis offers some insights for managers to carry out a systemic analysis of the institutional pressures that impinge on utility companies while developing CSR. Further, the paper offers a framework to analyse relevant logics for different kinds of companies, even though they are inserted in a single context. Additionally, whereby logics are divergent, we posit three possible strategies that allow a company to proactively address tensions among logics instead of dismissing them. Hence, the paper enables managers to face multiple and possibly contrasting logics in complex contexts, by clarifying the nature of the concurrent pressures, companies might experience and of the divergences that might arise. That might allow firms to bring their own contribution to sustainability, especially by proposing more sustainable options for production systems. Finally, the paper could be relevant also for policy-makers. Indeed, the results provide a systemic analysis of divergence among logics that firms 
might encounter while implementing CSR and sustainability strategies, thus suggesting policy-makers what aspects need to be monitored.

To conclude, we acknowledge the limitations of this paper. First, given that the research was carried out through a case study, the results cannot be generalized to other companies or other sectors. However, we argue that some of the dynamics highlighted are sector specific. Future research could extend the analysis to different industries. Indeed, we focus on a single environment to enable the study of the effect of institutional interplay on organizations, but it could be interesting to compare the Italian context with other contexts, such as for instance other EU countries, in order to enable also the study of the influence of different market structures (i.e., monopoly, oligopoly, competitive market). Additionally, the three cases present an analogous ownership structure (i.e., partially controlled by the local Municipalities) but it would be relevant to study also companies that present different ownership structures to study whether it is influent on how logics are perceived by the company.

Second, when addressing organizational choices, we used the organization as unit of analysis, considering the influence of the institutional pressure on the company as a whole. Future research could go into more depth, unpacking the relationships at the individual level, and understating how the interplay of institutional logics influences the individual decision-makers. Therefore, further research is expected to explore what are the criteria that lead the choices of the various managers and how they prioritize different CSR strategies.

Third, the paper does not allow to study whether the different approaches adopted by companies actually enable the achievement of the envisaged outcomes. A stream of research that deserves further attention is the one dealing with measurement of CSR performances as adequate measurement systems could enable the evaluation of the appropriateness of different CSR strategies, by measuring efficacy and efficiency of the adopted CSR models in connection with the surrounding institutional environment. 
AA1000. (2008). Assurance Standard 2008. https://www.accountability.org/standards/ (accessed 31 August 2018)

Aguilera, R.V., Rupp, D.E., Williams, C.A. and Ganapathi, J. (2007). Putting the S Back in Corporate Social Responsibility: A Multilevel Theory of Social Change in Organizations. The Academy of Management Review, 32(3), 836-863.

Amaeshi, K., Adegbite, E. and Rajwani, T. (2016). Corporate Social Responsibility in Challenging and Nonenabling Institutional Contexts: Do Institutional Voids matter?. Journal of Business Ethics, 134, 135-153.

Arena, M., Azzone, G. and Mapelli, F. (2018). What drives the evolution of Corporate Social Responsibility strategies? An institutional logics perspective. Journal of Cleaner Production, 171, 345-355.

Athanasopoulou, A. and Selsky, J.W. (2015). The social context of corporate social responsibility: enriching research with multiple perspectives and multiple levels. Business and Society, 54, 322-364.

Beschorner, T. and Hajduk, T. (2017). Responsible Practices are Culturally Embedded: Theoretical Considerations on Industry-Specific Corporate Social Responsibility. Journal of Business Ethics, 143-635.

Binder, A. (2007). For love and money: Organizations' creative responses to multiple environmental logics. Theory and Society, 36, 547-571.

Bowen, H.R. (1953). Social Responsibility of the Businessman. New York: Harper\&Row.

Brammer, S., Jackson, G. and Matten, D. (2012). Corporate Social Responsibility and Institutional theory: new perspectives on private governance. Socio-economic Review, 10, 3-28.

Buhmann, K. (2006). Corporate social responsibility: what role for law? Some aspects of law and CSR. Corporate Governance: International Journal of Business in Society, 6, 188-202.

Carroll, A.B. and Shabana, K.M. (2010). The Business Case for Corporate Social Responsibility: A Review of Concepts, Research and Practice. International Journal of Management Reviews, 12, 85-105.

Crane, A., Palazzo, G., Spence, L. J. and Matten, D. (2014). Contesting the value of "creating shared value". California Management Review, 56(2), 130-153.

Currall, S.C., Inkpen, A.C. (2002). A multilevel approach to trust in joint ventures. Journal of International Business Studies, 33(3), 479-495.

Damayanthi, S. and Gooneratne, T. (2017). Institutional logics perspective in management control research: A review of extant literature and directions for future research. Journal of Accounting \& Organizational Change, 13(4), 520-547. 
DiMaggio, P. (1988). Interest and agency in institutional theory, in: Zucker, L. (Eds.), Institutional patterns and culture. Ballinger Publishing Company, pp. 3-22.

Eisenhardt, K. M. (1989). Building Theories from Case Study Research. Academy of Management Review, 14, 532-550.

Fortanier, F., Kolk, A. and Pinkse, J. (2011). Harmonization in CSR reporting. Management International Review, 51, 1-41.

Friedland, R. and Alford, R.R. (1991). Bringing society back in: Symbols, practices, and institutional contradictions. In: Powell, W.W., DiMaggio, P.J. (Eds.), The New Institutionalism in Organizational Analysis: 232-263. Chicago: University of Chicago Press.

Frijns, J., Hofman, J. and Nederlof, M. (2013). The potential of (waste)water as energy carrier. Energy Conversion and Management, 65, 357-363.

Fuente, J.A., García-Sanchez, I.M. and Lozano, M.B. (2017). The role of the board of directors in the adoption of GRI guidelines for the disclosure of CSR information. Journal of Cleaner Production, 141, 737-750.

Gao, J. and Bansal, P. (2013). Instrumental and Integrative Logics in Business Sustainability. Journal of Business Ethics, 112, 241-255.

Gennari, F. and Salvioni, D.M. (2018). CSR committees on boards: the impact of the external country level factors. Journal of Management and Governance, 1-27.

Greenwood, M. (2007). Stakeholder engagement: beyond the myth of corporate responsibility. Journal of Business Ethics, 74, 315-327.

Greenwood, R., Raynard, M., Kodeih, F., Micelotta, E.R. and Lounsbury, M. (2011). Institutional Complexity and Organizational Responses. The Academy of Management Annals, 5, 317-371.

GRI - Global Reporting Initiative, 2018. G4 Sustainability Reporting Guidelines. https://www.globalreporting.org/information/g4/Pages/default.aspx (accessed 31 August 2018)

Hahn, T. and Figge, F. (2016). Why architecture does not matter: on the fallacy of sustainability balanced scorecards. Journal of Business Ethics, 1-17.

Hahn, T., Pinkse, J., Preuss, L. and Figge, F. (2015). Tensions in corporate sustainability: Towards an integrative framework. Journal of Business Ethics, 127, 297-316.

Halkos, G. and Skouloudis, A. (2017). Revisiting the relationship between corporate social responsibility and national culture: A quantitative assessment. Management decision, 55(3), 595-613. 
Harjoto, M.A. and Rossi, F. (2019). Religiosity, female directors, and corporate social responsibility for Italian listed companies. Journal of Business Research, 95, 338-346.

Hogarth, K., Hutchinson, M. and Scaife, W. (2016). Corporate Philanthropy, Reputation Risk Management and Shareholder Value: A Study of Australian Corporate giving. Journal of Business Ethics, 1-16.

IEA - International Energy Agency. (2018). International Energy Agency. www.iea.org (accessed 31 August 2018).

IFAC - International Federation of Accountants. (2018). International Standard on Assurance Engagements (ISAE) 3000 Revised, Assurance Engagements Other than Audits or Reviews of Historical Financial Information. https://www.ifac.org/publications-resources/international-standard-assurance-engagementsisae-3000-revised-assurance-enga (accessed 31 August 2018)

ISO - International Organization for Standardization. (2018). ISO 15686-1:2011 - Buildings and constructed assets -- Service life planning -- Part 1: General principles and framework. https://www.iso.org/standard/45798.html (accessed 31 August 2018)

Kumara, V., Gunasekaranb, A., Singha, K., Papadopoulosc, T. and Dubeyd, R. (2015). Cross sector comparison of sustainability reports of Indian companies: A stakeholder perspective. Sustainable Production and Consumption, 4, 62-71.

Jamali, D. and Keshishian, T. (2009). Uneasy alliances: lessons learned from partnerships between businesses and NGOs in the context of CSR. Journal of Business Ethics, 84, 277-295.

Jamali, D. and Neville, B. (2011) Convergence Versus Divergence of CSR in Developing Countries: An Embedded Multi-Layered Institutional Lens. Journal of Business Ethics, 102, 599-621

Junior, R.M., Best, P.J. and Cotter, J. (2014). Sustainability reporting and assurance: a historical analysis on a world-wide phenomenon. Journal of Business Ethics, 120, 1-11.

Lee, M.P. and Lounsbury, M. (2015). Filtering Institutional Logics: Community Logic Variation and Differential Responses to the Institutional Complexity of Toxic Waste. Organization Science, 26, 847-866.

Lindgreen, A. (2008) Managing Market Relationships. Farnham: Gower Publishing.

del Mar Miras-Rodríguez, M., Carrasco-Gallego, A. and Escobar-Pérez, B. (2015). Has the CSR engagement of electrical companies had an effect on their performance? A closer look at the environment. Business Strategy and the Environment, 24, 819-835.

Marano, V. and Kostova, T. (2016). Unpacking the Institutional Complexity in Adoption of CSR Practices in Multinational Enterprises. Journal of Management Studies, 53, 28-54. 
McWilliams, A., Parhankangas, A., Coupet, J., Welch, E. and Barnum, D.T. (2016). Strategic Decision Making for the Triple Bottom Line. Business Strategy and the Environment, 25, 193-204.

Melkonyan, A., Gottschalk, D. and Kamath, V.V.P. (2017). Sustainability assessments and their implementation possibilities within the business models of companies. Sustainable Production and Consumption, 12, 1-

Moon, J. (2007). The contribution of corporate social responsibility to sustainable development. Sustainable Development, 15, 296-306.

Moratis, L. (2016). Consequences of Collaborative Governance in CSR: An Empirical Illustration of Strategic Responses to Institutional Pluralism and Some Theoretical Implications. Business and Society Review, 121, 415-446.

Mouritsen, J. (1994). Rationality, institutions and decision making: Reflections on March and Olsen's rediscovering institutions. Accounting, Organizations and Society, 19(2), 193-211.

Nikolaou, I.E. and Matrakoukas, S.I. (2016). A framework to measure eco-efficiency performance of firms through EMAS reports. Sustainable Production and Consumption, 8, 32-44.

Ny, H., MacDonald, J.P., Broman, G., Yamamoto, R. and Robért, K.H. (2006). Sustainability constraints as system boundaries: an approach to making life-cycle management strategic. Journal of Industrial Ecology, 10, 61-77.

Porter, M.E. and Kramer, M.R. (2006). Strategy and Society: The Link Between Competitive Advantage and Corporate Social Responsibility. Harvard Business Review, 84(12), 78-93.

Porter, M.E. and Kramer, M.R. (2011). The Big Idea: Creating Shared Value. Harvard Business Review, 89.

Powell, W.W. and Colyvas, J.A. (2008). Microfoundations of institutional theory. In: Greenwood, R., Oliver, C., Sahlin, K., Suddaby, R. (eds.), The Sage handbook of organizational institutionalism, 276-298. SAGE Publishing.

Reed, M.S., Fraser, E.D.G. and Dougill, A.J. (2006). An adaptive learning process for developing and applying sustainability indicators with local communities. Ecological Economics, 59(4), 406-418.

Riley, J. (2001). Multidisciplinary indicators of impact and change: key issues for identification and summary. Agriculture, Ecosystems \& Environment, 87(2), 245-259.

Scherer, A. G. and Palazzo, G. (2011). The New Political Role of Business in a Globalized World: A Review of a New Perspective on CSR and its Implications for the Firm, Governance, and Democracy. Journal of Management Studies, 48, 899-931.

Scott, W.R. (1995). Institutions and Organizations. Thousand Oaks, CA: Sage. 
Skouloudis, A., Isaac, D. and Evaggelinos, K. (2016). Revisiting the national corporate social responsibility index. International Journal of Sustainable Development \& World Ecology, 23(1), 61-70.

Spitzeck, H., Boechat, C. and Leão, S.C. (2013). Sustainability as a driver for innovation - towards a model of corporate social entrepreneurship at Odebrecht in Brazil. Corporate Governance: The international journal of business in society, 13, 613-625.

Thornton, P.H. (2004). Markets from Culture: Institutional Logics and Organizational Decisions in Higher Education Publishing. Stanford: Stanford University Press.

8 Thornton, P. H. and Ocasio, W. (1999). Institutional logics and the historical contingency of power in 9 organizations: Executive succession in the higher education publishing industry, 1958-1990. American journal of Sociology, 105, 801-843. Thornton, P. H., Ocasio, W. and Lounsbury, M. (2012). The institutional logics perspective: A new approach to culture, structure, and process. Oxford University Press on Demand.

UNIDO - United Nations Industrial Development Organization, 2009. Value Chain Diagnostics for Industrial Young, S. and Makhija, M.V. (2014). Firms' Corporate Social Responsibility Behavior: An Integration of Institutional and Profit Maximization Approaches. Journal of International Business Studies, 45, 670-698.

UNIDO - United Nations Industrial Development Organization (2009). UNIDO - United Nations Industrial Development Organization (accessed 25 November 2018)

UNSD - United Nations Statistics Division. (2018). Statistics Division. https://unstats.un.org/home/ (accessed 25 November 2018)

Visser, W. (2012). The Future of CSR: towards Transformative CSR, or CSR 2.0. Kaleidoscope Futures Paper Series.

Wu, L., Subramanian, N., Abdulrahman, M.D., Liu, C.L., Pawar, K.S. (2017). Short-term versus long-term benefits: Balanced sustainability framework and research propositions. Sustainable Production and Consumption, 11, 18-30.

Yin, R. K. (1994). Case Study Research. Thousand Oaks: Sage Publications. 